\title{
Comparative yield of leguminous crops using different cultivation methods
}

\author{
Alexey V. Vasin, Veronika V. Rakitina*, Oksana P. Kozhevnikova, and Eugene V. Karlov \\ Samara State Agrarian University, Kinel 446442, Samara region, Russia
}

\begin{abstract}
Methods of increasing the yield of leguminous crops through the use of fertilizers and growth stimulants "Mival Agro", "Megamix", "Albite", "Avibif" and the bacterial preparation "Risotorfine" at different seed rates are described. The results of two experiments with an assessment of the yield of chickpea and pea are presented. The use of fertilizers and growth stimulants increases the crop yield by $2.53 \mathrm{t} / \mathrm{ha}$ for chickpeas and by $1.36 \mathrm{t} / \mathrm{ha}$ for peas.
\end{abstract}

\section{Introduction}

The main task of rural production in is to provide the population with enough food while preserving the environment [1]. Legumes are an important link in agricultural production. The protein content in the seeds of leguminous crops is 2-3 times higher than in wheat and barley and varies from 23 to $40 \%$ depending on varieties [2-5].

The need for a further increase in vegetable protein is associated with population growth. For a unit of animal protein, 3-7 units of vegetable protein are spent. The development of modern animal husbandry and innovation in the food industry require a constant increase in the production of vegetable protein [6]. Deficiency of vegetable protein can be compensated for by high-protein crops or by imported products [7]. Agricultural production has a wide variety of legumes (peas, lentils, vetch, chin, soy, beans, mung bean, chickpea, lupine). With an increase in cultivated areas, the preference should be given to those crops that meet the soil and climatic conditions of specific cultivation zones. This makes it possible to obtain the largest number of protein-balanced feeds per unit area [8].

Modern technologies should include environmentally friendly biologically active substances that increase productivity, product quality and plant resistance to adverse environmental factors and reduce the technogenic load on the soil [9]. In recent years, a large number of preparations have been developed for agricultural production. They can protect seeds and plants from pests and diseases. The use of growth-regulating drugs and plant protection products, treatment of plants allows us to provide seedlings with required nutrients, protect plants from various diseases, and increase the yield by $15 \%$ [10]. Many plant growth and development regulators with wide anti-stress effects influence the productive use of mobile forms of minerals, and increase plant resistance to environmental stresses, diseases, and pests [11-14].

Presowing treatment of seeds with bacterial preparations and micronutrient fertilizers becomes one of the important factors in the ecologization of agricultural production and makes it possible to obtain high, stable yields, while ensuring reproduction of soil fertility [15, 16].

The Department of Crop Production and Agriculture of Samara State Agrarian University carried out experiments on the crop rotation fields of the Korma research laboratory to develop methods for increasing the productivity of leguminous crops using biostimulants.

\section{Materials and methods}

\subsection{Objects}

The objects of research were: chickpea variety "Privo 1"; three options of mineral nutrition: control (without fertilizers); NPK per $1.8 \mathrm{t} /$ ha of grain (Option 1) and NPK per $2.2 \mathrm{t} /$ ha of grain (Option 2); growth stimulants: "Mival Agro", "Megamix", "Albite", as well as the bacterial drug "Risotorfine" (experiment 1); pea varieties - Flagman 12, Usaty Kormovoy; growth stimulants: Avibif, Megamix Universal; the seeding rate: $0.8 ; 1.0$; 1,$2 ; 1.4$ and 1.6 million germinating seeds / ha (experiment 2).

Mival-Agro is a plant growth stimulator, a complex preparation which crezacin. It is used for presowing treatment of seeds and spraying vegetative plants. It strengthens protective properties of plants, increases endurance to extreme weather conditions. Megamix is a liquid mineral fertilizer for foliar treatment with a rich content of trace elements. It stimulates root nutrition, activates enzymes and replenishes missing nutrients. "Albite" is a multifunctional drug of biological origin. The active ingredient Albite is a natural biopolymer of poly-

\footnotetext{
* Corresponding author: vvrakitina@mail.ru
} 
beta-hydroxybutyric acid from soil bacteria Bacillus megaterium and Pseudomonas aureofaciens. The unique mechanisms of action allow it to protect agricultural plants from a wide range of biotic (disease) and abiotic stresses. "Risotorfine" is an inoculant of highly effective nodule bacteria Rhizobium grown on a peat substrate or in a nutrient medium enriched with carbohydrates, minerals, and vitamins.

One gram of the drug contains at least 2.5 billion active nodule bacteria. Avibif is a plant growth regulator, a bioorganic, biologically active polymer compound with pronounced bactericidal and fungicidal properties. The active substance is poly- $\mathrm{N}, \mathrm{N}$-demethyl-3-4-dimethylene pyrrolidinium chloride.

In the experiments, the following varieties of legumes were studied: mid-season chickpea variety "Privo 1"; pea varieties - Flagman 12 (mid-season, leafless, determinant), Usaty Kormovoy (mid-ripening).

The aim of the research is to evaluate productivity of leguminous crops at different levels of mineral nutrition with the use of biostimulants for pre-sowing treatment of seeds at different seeding rates.

The research objectives are to identify the most productive leguminous crops, the most suitable methods for pre-sowing seed treatment and vegetation of legumes at different levels of mineral nutrition and at different rates of sowing.

\subsection{Methods}

The two-factor 2012-2014 experiment on different methods of presowing treatment of chickpea seeds and applying fertilizers and the three-factor 2015-2017 experiment on the effect of the norms of sowing peas when using growth stimulants for vegetation are incorporated in the crop rotation of the Department of Crop Production and Agriculture. The soil of the experimental plot is a chernozem, a residual carbonate, medium humus (medium thick, heavy loamy). Humidification is natural.

Agricultural technology typical of the region were used. Sowing was carried by an AMAZONE D9-25 seeder in the usual ordinary way, the crops were treated with growth stimulators according to the experimental scheme. Harvesting was carried out sublimely in the phase of full ripeness.

The two-factor experiment on different methods of presowing seed treatment and applying fertilizers included: three options of mineral nutrition: control without fertilizers; NPK per $1.8 \mathrm{t} /$ ha of grain (Option 1) and NPK per $2.2 \mathrm{t} /$ ha of grain (Option 2) (factor A); growth stimulants: Mival Agro, Megamix, Albite, as well as the bacterial drug Risotorfine (factor B).

In the three-factor experiment, when using growth stimulants during vegetation, there were the following options: control, Avibif, Megamix Universal (factor A); pea varieties - Flagman 12, Mustachioed Fodder (factor $\mathrm{B})$; the seeding rate: $0.8 ; 1.0 ; 1,2 ; 1.4$ and 1.6 million germinating seeds / ha (factor C).
Accounting for grain yield was determined by the method of continuous harvesting of plots with subsequent conversion to $14 \%$ humidity.

In 201202014, weather conditions were different. In 2012, May and summer were warm, which contributed to phenological phases. In 2013, chickpeas were sown on May 13. Shoots developed six days (May 18) after sowing. The difference in the development of seedlings was 1-2 days. Warm weather and no precipitation contributed to the flowering phase which occurred 25-27 days after the germination. In 2014, chickpeas were sowed on May 12. The development phases did not have large differences. In 2015 - 2017, weather conditions can be described as favorable for the crops.

\section{Results}

The main indicator of the economic value of annual crops is the size and quality of the crop. Observations showed that the yield depends on the cultivated crop, the level of mineral nutrition, the seeding rate, seed treatment with growth stimulants and weather conditions.

Currently, a large number of scientists are studying chickpeas in order to obtain higher yields, improve grain quality and cultivation technologies.

Fertilizing, as well as pre-sowing seed treatment increased the chickpea yield in the experiment (Table 1).

Over the years of research, the yield of chickpeas has been uneven. 2013 and 2014 were more favorable. When using fertilizers, the yield increased.

On average, over three years of research, chickpea yields were in the range of 1.53-2.53 t / ha. The best yield was obtained by applying fertilizers in the amount of 2.2 $\mathrm{t} / \mathrm{ha}$ and treating seeds with Megamix andRisotorfine and Mival Agro and Risotorfine (2.53 t / ha and $2.48 \mathrm{t} / \mathrm{ha}$, respectively).

The planned yield of chickpeas was obtained in all options. The program for the planned yield of $2.2 \mathrm{t} /$ ha of grain was fulfilled by all the options, except for the option without seed treatment. The maximum implementation of the program was ensured when using Risotorfine and Megamix (115\%).

Peas is the main leguminous crop which is widespread. According to the combination of economically valuable traits of varieties, Usaty Kormovoy variety has no analogues. The main economic advantage of the new variety is increased manufacturability. In the mowing phase (the end of flowering), the plants stand.

In the standard variety, lodging of grass stands is observed in the budding phase. The problem of obtaining high-quality fodder is still one of the most acute. Highyielding peas of mowing and forage use appear in the crops. In this regard, it became necessary to study the responsiveness of Flagman 12 to growth stimulants, to correct its seeding rate and evaluate the yield of Usaty Kormovoy pea variety.

Observations found that the crop yield depends on the cultivated crop, the level of mineral nutrition and weather conditions. 
Table 1. Chickpeas yield depending on pre-sowing seed treatment methods at different levels of mineral nutrition, 2012-2014, $\mathrm{t} / \mathrm{ha}$

\begin{tabular}{|c|c|c|c|c|c|}
\hline \multirow{2}{*}{ Option } & \multicolumn{4}{|c|}{ Obtained from 1 ha, $\mathrm{t}$} & \multirow{2}{*}{$\begin{array}{c}\text { Program } \\
\text { implemented } \\
\%\end{array}$} \\
\hline & 2012 & 2013 & 2014 & average & \\
\hline \multicolumn{6}{|c|}{ Control } \\
\hline Control & 1.32 & 1.76 & 1.50 & 1.53 & - \\
\hline Mival Agro & 1.68 & 2.11 & 1.46 & 1.75 & - \\
\hline Megamix & 1.63 & 2.14 & 1.54 & 1.77 & - \\
\hline Albite & 1.46 & 1.84 & 1.52 & 1.61 & - \\
\hline Risotorfine & 1.51 & 1.94 & 1.50 & 1.65 & - \\
\hline Risotorfine+Mival Agro & 1.89 & 2.24 & 1.52 & 1.88 & - \\
\hline Risotorfine+Megamix & 1.96 & 2.20 & 1.53 & 1.90 & - \\
\hline Risotorfine+Albite & 1.83 & 2.13 & 1.61 & 1.86 & - \\
\hline \multicolumn{6}{|c|}{ Option 1} \\
\hline Control & 1.56 & 1.94 & 2.21 & 1.90 & 105.6 \\
\hline Mival Agro & 1.83 & 2.28 & 2.23 & 2.11 & 117.2 \\
\hline Megamix & 1.88 & 2.24 & 2.18 & 2.10 & 116.7 \\
\hline Albite & 1.74 & 2.11 & 2.10 & 1.98 & 110.0 \\
\hline Risotorfine & 1.76 & 2.18 & 2.23 & 2.06 & 114.4 \\
\hline Risotorfine+Mival Agro & 2.03 & 2.36 & 2.36 & 2.25 & 125.0 \\
\hline Risotorfine+Megamix & 2.27 & 2.37 & 2.38 & 2.34 & 130.0 \\
\hline Risotorfine + Albite & 2.01 & 2.26 & 2.24 & 2.17 & 120.6 \\
\hline \multicolumn{6}{|c|}{ Option 2} \\
\hline Control & 1.77 & 2.28 & 2.31 & 2.12 & 96.4 \\
\hline Mival Agro & 1.98 & 2.51 & 2.43 & 2.31 & 105.0 \\
\hline Megamix & 2.06 & 2.53 & 2.58 & 2.39 & 108.6 \\
\hline Albite & 1.97 & 2.37 & 2.50 & 2.28 & 103.6 \\
\hline Risotorfine & 2.03 & 2.30 & 2.41 & 2.25 & 102.3 \\
\hline Risotorfine+Mival Agro & 2.19 & 2.56 & 2.69 & 2.48 & 112.7 \\
\hline Risotorfine+Megamix & 2.38 & 2.48 & 2.74 & 2.53 & 115.0 \\
\hline Risotorfine+Albite & 2.06 & 2.43 & 2.64 & 2.38 & 108.2 \\
\hline LSD 0.5 total & 0.03 & 0.03 & 0.12 & & \\
\hline $\mathrm{A}$ & 0.01 & 0.01 & 0.04 & & \\
\hline B. $A B$ & 0.02 & 0.02 & 0.07 & & \\
\hline
\end{tabular}

The effect of growth stimulants is evident. The best yield in 2015 was shown when treating crops with Megamix Universal: the yield of Flagman 12 varied from 1.18 to $1.47 \mathrm{t} / \mathrm{ha}$. Usaty Kormovoy produced a slightly lower yield - $1.03 \ldots 1.38 \mathrm{t} /$ ha (Table 2).

In 2016, the highest yield was obtained when treating with Megamix Universal: Usaty Kormovoy $-1.18 \ldots 1.42$ $\mathrm{t} / \mathrm{ha}$, Flagman $12-2.00 \ldots 2.24 \mathrm{t} / \mathrm{ha}$.

Analyzing the average yield for three years of research, we see that the optimal seeding rate for Flagman 12 peas is 1.2 million germinating seeds per ha (the yield was $1.47 \mathrm{t} / \mathrm{ha}$ (control), $1.84 \mathrm{t} /$ ha (Avibif), $1.94 \mathrm{t} / \mathrm{ha}$ (Megamix Universal).

Usaty Kormovoy had the largest yield with a sowing rate of 1.2 million germinating seeds per ha $-1.21 \mathrm{t} /$ ha (control), $1.28 \mathrm{t} / \mathrm{ha}$ (Avibif), $1.36 \mathrm{t} / \mathrm{ha}$ (Megamix Universal).

Thus, the analysis shows that the integrated application of fertilizers and growth stimulants increase the yield of leguminous crops. The cultivation of new varieties makes it possible to obtain high yields with minimal losses. 
Table 2. Yield of pea varieties in 2015 - 2017, t/ha

\begin{tabular}{|c|c|c|c|}
\hline Vegetation treatment & Varieties & Seeding rate, mln. seed & Yield, t/ha \\
\hline \multirow{10}{*}{ 栉 } & \multirow{5}{*}{ Flagman 12} & 0.8 & 1.25 \\
\hline & & 1.0 & 1.35 \\
\hline & & 1.2 & 1.47 \\
\hline & & 1.4 & 1.43 \\
\hline & & 1.6 & 1.42 \\
\hline & \multirow{5}{*}{ Usaty Kormovoy } & 0.8 & 0.98 \\
\hline & & 1.0 & 1.13 \\
\hline & & 1.2 & 1.21 \\
\hline & & 1.4 & 1.21 \\
\hline & & 1.6 & 1.20 \\
\hline \multirow{10}{*}{$\begin{array}{l}\frac{4}{3} \\
\frac{7}{4}\end{array}$} & \multirow{5}{*}{ Flagman 12} & 0.8 & 1.60 \\
\hline & & 1.0 & 1.73 \\
\hline & & 1.2 & 1.84 \\
\hline & & 1.4 & 1.80 \\
\hline & & 1.6 & 1.74 \\
\hline & \multirow{5}{*}{ Usaty Kormovoy } & 0.8 & 1.03 \\
\hline & & 1.0 & 1.21 \\
\hline & & 1.2 & 1.28 \\
\hline & & 1.4 & 1.24 \\
\hline & & 1.6 & 1.21 \\
\hline \multirow{10}{*}{ 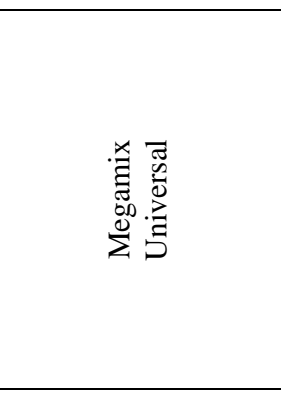 } & \multirow{5}{*}{ Flagman 12} & 0.8 & 1.74 \\
\hline & & 1.0 & 1.82 \\
\hline & & 1.2 & 1.94 \\
\hline & & 1.4 & 1,92 \\
\hline & & 1.6 & 1.90 \\
\hline & \multirow{5}{*}{ Usaty Kormovoy } & 0.8 & 1.15 \\
\hline & & 1.0 & 1.29 \\
\hline & & 1.2 & 1.36 \\
\hline & & 1.4 & 1.33 \\
\hline & & 1.6 & 1.35 \\
\hline & \multirow{2}{*}{\multicolumn{2}{|c|}{$\mathrm{LSD}_{05}$ total }} & 0.04 \\
\hline & & A & 0.01 \\
\hline & & 0.01 \\
\hline & \multicolumn{2}{|r|}{$\mathrm{C}$} & 0.02 \\
\hline
\end{tabular}

\section{Discussion}

The legumes respond differently to fertilizer and growth stimulants. At all levels of mineral nutrition, the best values were obtained when applying Megamix and Risotorfine and Mival Agro and Risotorfine.

Megamix Universal was the best growth stimulator. The optimum seeding rate for peas is 1.2 million germinating seeds per ha.

\section{Conclusion}

Legumes are able to produce a crop in the range of 1.53$2.53 \mathrm{t} / \mathrm{ha}$. The use of fertilizers in conjunction with growth stimulators Megamix increases the yield crop by $1.94-2.53 \mathrm{t} /$ ha.

\section{References}

1. G. V. Blagoveshchensky, Feed Production 12, 8-9 (2013)

2. M. Seidel, Saat - und Pflanzgut 26, 123-124 (1985)

3. D. Shpaar, Legumes 8 (2000)
4. P.A. Chekmarev, Achievements of science and technology of the agro-industrial complex 6, 5-8 (2011)

5. M.E. Belyshkina, Environmental management 2, 6572 (2018)

6. V.I. Zotikov, Agriculture 4, 6-8 (2014)

7. J.E. Board, C.S. Kahlon, Soybean Physiology and Biochemistry (2011)

8. N. Kashevarov, Chief livestock specialist 12, 27 (2010)

9. M.T. Golopyatov, Legumes and cereals 2, 62 (2012)

10. A.I. Erokhin, Legumes and cereals 1(5), 55-56 (2013)

11. A.I. Erokhin, Legumes and cereals 2(6), 120 (2013)

12. A.A. Gromov, Bulletin of Orenburg State Agrarian University, 1(21), 16-18 (2009)

13. N.Yu. Fomina, Agrarian Bulletin of the Urals 3(54), 61-63 (2009)

14. I.N. Gainanov, Bulletin of Kazan SAU 3(33), 107-109 (2014)

15. V.G. Vasin, Bulletin of Samara State Agricultural Academy 4, 7-10 (2014)

16. T.F. Persikova, Fertility 1, 19-20 (2006) 